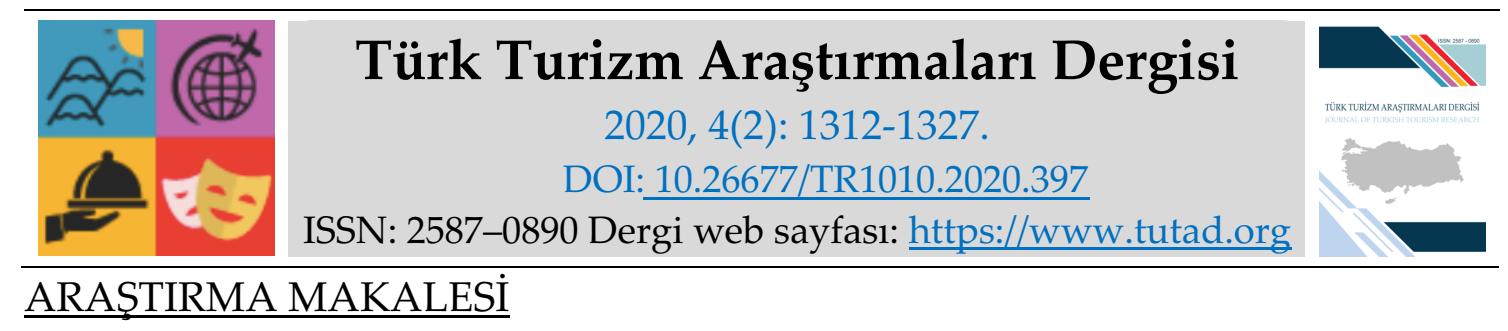

\title{
Uluslararası Uçuşlardaki Türk Mutfağına Ait Ürünlerin Yer Aldığı Menülerin Değerlendirilmesi: Uçan Şefler Üzerine Bir Araştırma
}

Funda UĞRAÇ, Doktora Öğrencisi, İstanbul Gelişim Üniversitesi, Sosyal Bilimler Enstitüsü, İstanbul, e-posta: funda.ugrac@doco.com.tr

ORCID: https://orcid.org/0000-0002-3843-3122

Öğr. Gör. Arif Emre ERDEN, TC. İstanbul Şişli Meslek Yüksekokulu, İstanbul, e-posta: emre.erden@sisli.edu.tr

ORCID: https://orcid.org/0000-0002-3863-3511

Fatih Kürşat NEGÜZEL, Doktora Öğrencisi, İstanbul Gelişim Üniversitesi, Sosyal Bilimler Enstitüsü, İstanbul, e-posta: fkneguzell@gmail.com

ORCID: https://orcid.org/0000-0002-3843-3122

Dr. Öğr. Üyesi Özgür KIZILDEMIR, İstanbul Gelişim Üniversitesi, Uygulamalı Bilimler Yüksek Okulu, İstanbul, e-posta: o.kizildemir@gmail.com

ORCID: https://orcid.org/0000-0003-4040-4547

Öz

$\mathrm{Bu}$ araştırmada uluslararası uçuşlardaki Türk mutfağına ait ürünlerin yer aldığı menülerin değerlendirilmesi amaçlanmıştır. Bunu yaparken de bu ürünleri yolcular için hazırlayan uçan şeflerin gözlem ve görüşlerinden faydalanılmıştır. Çalışmada 20 uçan şefle yarı yapılandırılmış görüşme formu kullanılarak, yapılan görüşmeler sonucu elde edilen veriler değerlendirilmiştir. Elde edilen bulgular yabancı yolcuların genel olarak Türk mutfağına ait ürünlere karşı olumlu görüş bildirdiklerini göstermiştir. Kebap, baklava, Maraş dondurması, demleme çay ve Türk kahvesi gibi bazı ürünlerin yolcular tarafından bilindiği ve daha çok talep edildiği tespit edilmiştir. Buna karşın yaprak sarma ve irmik helvası gibi bazı ürünlerin ise yolcular tarafından tam olarak algılanamadığı ve daha az tercih edildiği görülmüştür. Uçan şeflerden alınan bilgilerden yola çıkılarak yolcuların Türk yemek ve içeceklerini bilmedikleri için risk almak istememeleri, yemekleri yağlı ve baharatlı bulmaları, Türk yemek ve içeceklerinin kültürlerine uymaması gibi nedenler Türk mutfağını tercih etmeme nedenleri arasında yer almaktadır. Türk mutfağını tercih etmeyen yolcuların en çok dünya mutfaklarına yöneldiği belirlenmiştir

Anahtar Kelimeler: Havayolu Taşımacılığı, Uluslarası Uçuşlar, Uçan Şef, Menü, Türk Mutfağı.

Makale Gönderme Tarihi: 30.12.2019

Makale Kabul Tarihi: 08.04.2020

\section{Önerilen Atıf:}

Uğraç, F., Erden, A. E., Negüzel, F. K. ve Kızıldemir, Ö. (2020). Uluslararası Uçuşlardaki Türk Mutfağına Ait Ürünlerin Yer Aldığı Menülerin Değerlendirilmesi: Uçan Şefler Üzerine Bir Araştırma, Türk Turizm Araştırmaları Dergisi, 4(2): 1312-1327.

(C) 2020 Türk Turizm Araştırmaları Dergisi. 


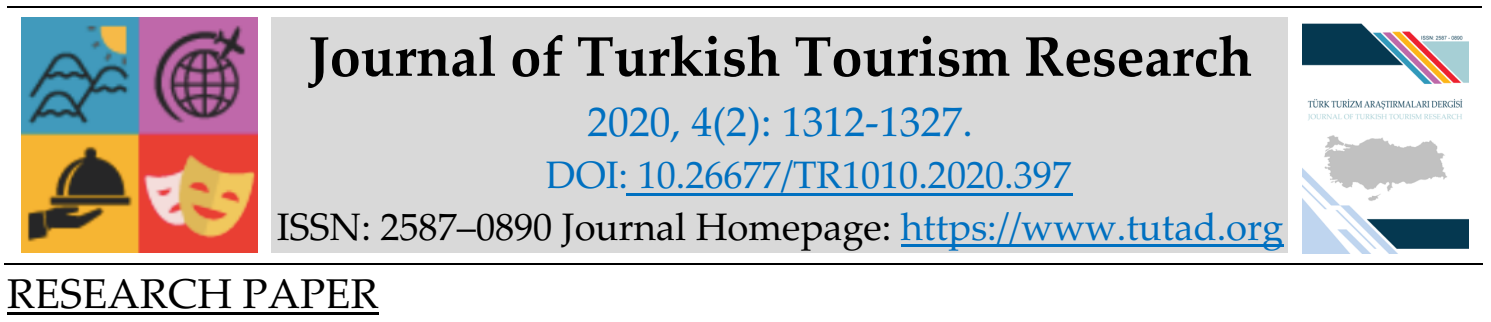

\title{
Evaluation on the Menus in International Flights Which Include the Items of Turkish Cuisine: A Research on the Flying Chefs
}

Funda UĞRAÇ, Ph.D. Student, İstanbul Gelişim University, Social Science Institute, İstanbul, email: funda.ugrac@doco.com.tr ORCID: https://orcid.org/0000-0002-3843-3122

Lecturer Arif Emre ERDEN, TC. İstanbul Şişli Vocational School, İstanbul, e-mail: emre.erden@sisli.edu.tr ORCID: https://orcid.org/0000-0002-3863-3511

Fatih Kürşat NEGÜZEL, Ph.D. Student, İstanbul Gelişim University, Social Science Institute, İstanbul, e-mail: fkneguzell@gmail.com ORCID: https://orcid.org/0000-0003-0885-0811

Assistant Prof. Dr. Özgür KIZILDEMIR, İstanbul Gelişim University, School of Applied Sciences, İstanbul, e-mail: o.kizildemir@gmail.com ORCID: https://orcid.org/0000-0003-4040-4547

\begin{abstract}
The aim of this study is to evaluate the menus of the Turkish cuisine on international flights. In this study, observations and opinions of flying chefs who prepare products for passengers were used. The data obtained from the interviews with 20 flying chefs using semi-structured interview form were evaluated. The findings show that foreign passengers generally have a positive opinion about the products of Turkish cuisine. Some products such as kebab, baklava, Maras ice cream brewed tea and Turkish coffee are known and demanded by the passengers. On the other hand, some products such as stuffed vine leaves and semolina halva were not perceived enough by the passengers and less preferred. According to the information received from the flying chefs, the passengers do not want to take risks because they don't know Turkish food and drinks, they think Turkish food is greasy and spicy, the Turkish food and drinks do not fit their culture, such as reasons why they don't prefer Turkish cuisine. Passengers who didn't prefer Turkish cuisine were most likely to prefer the International Cuisine.
\end{abstract}

Keywords: Airline Transport, International Flights, Flying Chef, Menu, Turkish Cuisine.

Received: 30.12.2019

Accepted: 08.04.2020

\footnotetext{
Suggested Citation:

Uğraç, F., Erden, A. E., Negüzel, F. K. and Kızıldemir, Ö. (2020). Evaluation on the Menus in International Flights Which Include the Items of Turkish Cuisine: A Research on the Flying Chefs, Journal of Turkish Tourism Research, 4(2): 1312-1327.

(C) 2020 Türk Turizm Araştırmaları Dergisi.
} 


\section{GİRIŞ}

İnsanların, diğer canlıların ve insanoğlunun ürettiği ürünlerin çeşitli araçlarla bir yerden başka bir yere taşınması faaliyetleri olarak bilinen ulaştırmanın tarihsel süreç içerisinde çok büyük bir çeşitliliğe ulaştığını söylemek mümkündür. Ulaşımın tarihsel gelişiminde bazı dönüm noktaları bulunmaktadır. Bu en önemli dönüm noktalarından birinin motorun icadı ve onun farklı amaçlarla kullanılma arayışı olduğu bilinmektedir. Bu arayış sürecinde havayolu ulaşımında da Wright Kardeşler'in uçması gibi önemli anlar bulunmaktadır. I. ve II. Dünya Savaşı sırasında özellikle askeri alanda kullanılan hava araçları daha sonra yaşanan teknolojik ve toplumsal gelişmeler sonucu sivil taşımacılıkta da kullanılmaya başlanmıştır. Giderek artan talep ve olanakların günümüzde ülkelerin havayolu firmalarının daha fazla yatırım yapmasına ve sektörün gelişmesine zemin hazırladığından söz etmek mümkündür (Bakırcı, 2012).

Havayolu firmalarının halihazırdaki müşterilerini kaybetmemek ve daha çok müşteri kapasitesine ulaşabilmek için uçuşlarda servis edilen yiyecek ve içeceklerin servisi ile ilgili de yeni uygulamalar yaptığı bilinmektedir. Uçaklarda müşterilere sunulan ikramların artık lüks lokantalardaki hizmet seviyelerine geldiğini söylemek mümkündür. Bunun yanında uçaklarda yolculara sunulan yiyecek ve içeceklerin müşterilerin zevklerine, inançlarına, yaşam tarzlarına, yaşına, sağlık durumlarına, isteklerine göre uçuş öncesinde detaylı olarak düşünülüp bir menü planlaması yapılabilmektedir. Türk havayolu firmaları dünya mutfaklarından birçok yemeğin yanında Türk mutfağından da yiyecek ve içecek hazırlayarak ülke turizmine ve mutfak kültürümüzün tanıtılmasına katkı sağlamaktadır. Bu yiyecek ve içeceklerin sunumu için dünyada ve Türkiye' de birçok havayolu firması kabin ekibine uçan şefleri de ekleyerek havayolu ulaşımının kalitesini arttırmayı hedeflemektedir. Uçaklarda yiyecek ve içeceklerin hazırlanması ve sunumundan sorumlu aş̧̧larla ile ilgili dünyada birçok önemli havayolu firmasının uygulaması bulunmaktadır. ETIHAD Airways "Inflight Chef", Gulf Air "Sky Chefs", Austrian Airlines ve THY ise bu uygulama için "Uçan Şef" adını kullanmaktadır (www.superadrianme.com). Uçan şef uygulamasının Türkiye'de Türk Hava Yolları ve Turkish DO\&CO işbirliğiyle first class ve business class uçuşlarda hizmete sunulan ve günümüzde diğer firmaların bazılarının da uyguladığı yüksek kalite standartlarında bir hizmet olduğu bilinmektedir. Uçan şefler uçuşlarda diğer ikram hizmetlerine ek olarak yolcunun isteğine göre daha önceden hazırlanan yemekleri ısıtma ve estetik bir şekilde servise hazır hale getirme gibi görevleri yerine getirmektedir. Uçan şefler aynı zamanda servis esnasında yolcuların istekleri ve sorunlarıyla yakından ilgilenmektedir (www.airnewstimes.com). Bu açıdan bakıldığında şeflerin mesleği ile ilgili deneyimli olması, yolcularla iyi iletişim kurabilmesi, yabancı dillerinin iyi olması, iş ahlakına ve takım ruhuna önem vermesi gibi özelliklere sahip olmaları gerekmektedir.

$\mathrm{Bu}$ araştırmanın amacı uluslararası uçuşlardaki Türk mutfağına ait ürünlerin yer aldığı menülerin değerlendirilmesidir. Bu amaca yönelik olarak yolcuların yemek seçimi ile ilgili tutumları, fikirleri ve dönütlerinin uçan şeflerin gözünden belirlenmesi hedeflenmektedir. Araştırma kapsamında havayolu şirketinin uluslararası yemeklerin yanında, menülerinde hangi Türk yemeklerini bulundurduğu, Türk yemeklerinin yolcular tarafından tercih edilme durumları ve yolcuların Türk mutfağına ait fikirlerinin tespit edilmesi amaçlanmaktadır. Literatüre bakıldığında havayolu firmalarının uzun mesafeli uçuşlarında içinde Türk yemeklerinin bulunduğu menülerle ilgili uçan şeflerin fikirlerine ait araştırmaların çok sınırlı sayıda olduğu tespit edilmiştir. Bu açıdan araştırmanın literatüre önemli katkı sağlayacağ yapılacak çalışmalara yol göstereceği düşünülmektedir. 


\section{KAVRAMSAL ÇERÇEVE}

\section{Havayolu Ulaşımının Tarihsel Gelişimi, Dünyadaki ve Türkiye'deki Mevcut Yapısı}

Modern havacılık tarihinin 17 Aralık 1903 tarihinde Wright kardeşlerin yaptığı ilk kontrol edilebilir uçuş denemesi ile başladığı söylenebilmektedir. Wright Kardeşler'in yaptığı bu uçuş denemesininsadece 12 saniye sürmesine rağmen tarihte önemli bir yer elde ettiğini söylemek mümkündür (Kane, 1990). I. Dünya Savaşı sürecinde önemli bir rol oynayan uçağın havacılığa olan ilgiyi arttırdığı ve bu ilginin daha sonra havacılı̆̆ın ticarileşmesine zemin hazırladığ bilinmektedir (Chuang, 1971). II. Dünya Savaşı'ndan sonra dünya havayolu taşımacilığının diğer ulaşım yollarından daha hızlı olması sebebiyle sürekli gelişen bir çizgi izlediği görülmektedir. Kitle turizmi ile birlikte 1950'li yılların başında başlayan havayolu yolcu taşımacılığının özellikle denizaşırı veya uzak mesafeli seyahat imkanını geliştiren bir taşımacılık türü halini aldığı bilinmektedir. Paket tur olarak adlandırılan ve yer hizmetlerini de içeren organize seyahatler zaman faktörünü önemseyen tüketicilerin tercih ettiği bir ulaşım tarzı haline gelmektedir (Ahipaşaoğlu, 2003). İnsanların turizm amaçlı seyahatleri başladığı andan itibaren havayolu taşımacılığının da önem kazanmaya başladığı ifade edilmektedir. Havayolu taşımacılığı sektöründe yaşanan serbestleşme eğilimi tüm dünyada hızlı bir şekilde yayılmaktadır. Serbestleşme, küreselleşme ve ticarileşme eğilimlerinin bir sonucu olarak havayolu taşımacılığında yolcu istek ve ihtiyaçlarına uygun hizmet çeşitliliğinin gelişimi sonucu yaratılan arza yüksek talep doğmaktadır. Dünya genelinde kişi başına düşen gelirin artması, bölgeler arası ticaretin ve turizmin gelişmesi sektöre olan talepteki büyüme oranını hızlandırmaktadır (TÜBİTAK, 2003). Hız, konfor ve güvenliğe ilişkin talep ve ihtiyaçlar, ulaşım sistemlerinde bir çeşitlenmeyi beraberinde getirmektedir. Bu çeşitlenme aynı zamanda ulaşım sistemleri arasında büyük bir rekabeti de tetiklemekte, ülkeler bu rekabette üstün gelebilmek amaciyla bu alandaki yatırımlarını arttırmaktadır (Bakırcı, 2012).

İnsanoğlunun tarih boyunca özgürlüğe, gezgin olmaya ve coğrafi engelleri aşmaya olan isteği onu üretmeye ve keşfetmeye yönlendirmiştir. Bu üretme ve keşfetme sürecinde havayolu ulaşımında bazı dönüm noktaları bulunmaktadır. Bu dönüm noktalarından birinin 1783 yılında Jacques ve Joseph Montgolfier kardeşlerin ilk sıcak hava balonunu uçurması olduğu söylenebilir. 1843 yılında ilk Pervaneli Uçak patenti William Samuel Henson tarafından alınmıştır. 1856 yılında bir Fransız denizci olan Kaptan Le Bris, Ümit Burnu civarında gördüğü albatros kuşundan çok etkilenmiş ve albatros kuşunun bire bir kopyası olan ilk planörü yapmıştır. 1874 yılında tümü alüminyum kullanılarak yapılmış kendi gücü ile uçan ilk uçak, Fransa' da M. Luis ve Felix du Temple tarafından yapılmıştır. 1900 yılında ilk zeplin uçuşu Ferdinand von Zeppelin tarafından yapılmıştır. 1903 yılında Wright Kardeşler kendi ürettikleri uçak pervanesiyle ilk denemelerinde 12 saniye havada kalmış ve 37 metre yol kat etmiştir. 1907 yılında Louis Bleriot ilk defa üzeri kapalı, önde tek motorlu, tek kanat ve kuyruk düzeni ile günümüzün uçak modelini yapmıştır. 1908 yılında Henry Farman 17 dakikada 95 km hızla uçarak, dünyada ilk şehirlerarası uçuşu gerçekleştirmiş̧tir. 1908 yılında dünyanın ilk havaalanı Port Aviation adıyla Paris'in 19 km dışında açılmıştır. 1911 yılında Pierre Prier hiç iniş yapmadan Londra'dan Paris'e yolcu taşıyarak ilk aktarmasız uçuşu yapmıştır. 1911 yılında ilk uçuşu, tamir edilen gözlüklerinin New York'dan Philadelphia'ya ulaştırılması amacıyla bir tüccar için yapılmıştır. 1933 yılında İngiltere'den Güney Afrika'ya ilk duraksız uçuş yapılmıştır. 1945 yılında IATA (Uluslararası Hava Taşıyıcıları Birliği) Küba'da kurulmuştur. 1947 yılında ilk süpersonik uçuş (sesten hızlı) yapılmıştır. 1968 yılında sesten hızlı Aeroflot'a ait yolcu uçağı ilk uçuşunu gerçekleştirmiştir. 1970 yılında dünyanın en büyük yolcu uçağı üreticisi olan Airbus S.A.S kurulmuştur. 1976 yılında sesten hızlı 
Concorde yolcu uçağı düzenli uçuşlara başlamıştır. 2005 yılında dünyanın en büyük yolcu uçağ 1 olan Airbus A380 Fransa' da tanıtılmıştır.

Türkiye açısından bu sürece bakılacak olursa, Türk havacıllk tarihinin bilinen ilk ismi Ebu İsmail Cevheri 1010 yılında kanatla uçmayı denemiştir. Daha sonra Siracettin Doğulu, 1159 yılında bir kutlama töreninde kanatla uçma denemesi yapmış, ardından da 1600 yılında Hezarfen Ahmet Çelebi kendi yaptığı kanatlarla Galata'dan Üsküdar'a uçarak 6 km katetmiş ve 5 dakika havada kalmıştır. Lagari Hasan Çelebi, 17. yüzyılın başlarında barut dolu haznesi bulunan bir hava roketi ile ilk dikey uçuşu başarıyla gerçekleştirmiştir. 1896 yılında Türkiye'nin ilk uçak tasarımcısı ve üreticisi Vecihi Hürkuş dünyaya gelmiştir. Vecihi K adını verdiği uçak kendi tasarımıdır. 1912 yılında Türkiye'nin ilk havaalanı Yeşilköy ile Sefaköy arasında bugünkü Atatürk Havalimanı'nın hemen yakınında Yeşilköy Havaalanı olarak açılmıştır. 1913 yılında Türkiye'nin ilk kadın pilotu ve dünyanın ilk kadın savaş pilotu olan Sabiha Gökçen doğmuştur. 1925 yılında Mustafa Kemal Atatürk'ün emriyle Türk Tayyare Cemiyeti kurulmuş, 1935 yılında ismi Türk Hava Kurumu olarak değiştirilmiştir. 1925 yllında Tayyare Otomobil ve Motor Türk Anonim Şirketi kurulmuştur. Türk Hava Yolları 20 Mayıs 1933 tarihinde Havayolları Devlet İşletme İdaresi olarak kurulmuştur. Türk Hava Yollarl, Türkiye'nin ulusal havayolu şirketidir. Şubat 1933'de İstanbul-Ankara arasında gerçekleştirilen ilk uçuşla, sivil uçuşlar başlamıştır. 1944 yılında Türkiye'nin ilk yerli üretim uçağı NU D.38 İstanbul'dan Ankara'ya uçuşunu başarıyla tamamlanmıştır. Yeşilköy Havaalanı adı 1985 yılında, Atatürk Havalimanı olarak değiştirilmiştir.2001 yılında Sabiha Gökçen Havalimanı 8 Ocak 2001 tarihinde trafiğe açılmıştır. 29 Ekim 2018 yılında ise İstanbul Yeni Havalimanı Arnavutköy'de açılmıştır (www.gatairlines.com).

\section{Havayolu İşletmeciliğinde Sunulan İkram Hizmetleri ve Menü Planlama}

Uçuş-içi yiyecek içecek hizmetleri 1914 yılındaki zeplin seferlerine dayanmaktadır. Bu seferlerde yolculara yemek ve şampanya ikram edilmiş, daha sonra zeplinde yolculara şeflerin hazırladığı sıcak yemekler ikram edilmeye başlanmıştır. Kayıtlı ilk uçuş-içi yemek servisi 1927 yılında AirUnion tarafından gerçekleştirilmiştir. Kabin memurları tarafından servis edilen bu menünün içeriğinde; ordövr tabağı, sstakoz salatası, soğuk tavuk ve jambon, nicoise salatası, peynir, meyve tabağ 1 ve dondurma bulunmaktadır. Yemeklerin yanısıra şampanya, şarap, viski, kahve ve su seçeneklerini içeren bir içecek menüsü de servis edilmiştir (Jones, 2004). 1928 yılında ise PanAm, üniformalı kabin memurlarını işe almış ve servislerde içinde çiçekler olan vazolar ve gümüş yemek takımları kullanmaya başlamıştır (Dana, 1999). İlk tam sıcak yemek servisi ise 1928 yılında Lufthansa tarafından Berlin-Paris hattında uçan 15 kişilik B-31 uçağında gerçekleşmiştir (Jones, 2004). 1930'lu yıllarda rotalar uzamaya başlamış ve 1934 yılında Qantas ve Imperial Havayolları operasyon güçlerini birleştirip kıtalararası uçuşları hizmete sokmuştur. Bu uçuşlarda yalıtımlı kutularda saklanan sıcak yemekler yolculara servis edilmeye başlanmış ve uçaklar uzun uçuşlarda sipariş üzerine yemeklerin isıtılmasına olanak sağlayan mutfak sistemiyle donatılmıştır. 1938 yılında Imperial Havayolları bugünün "Catering Merkezi" olarak adlandırabileceğimiz oluşumun temellerini ilk defa atmıştır (Dana, 1999). 1980'lerin ortasında havayollarının kendi catering mutfaklarını elden çıkartıp catering hizmeti için taşeron firmaları kullanmaya başlamasıyla sektör daha da gelişmiştir (Pilling, 2001). Günümüzde geçmişe göre gittikçe profesyonel hale gelen ikram hizmetleri küçük ikramların dışında havayolu firmalarının anlaşmalı olduğu catering şirketleri tarafından yürütülmektedir. Dünyanın önde gelen havayolu catering (ikram) şirketlerinden bazıları LDG Sky Chefs (Alman firması Lufthansa'ya ait), Gata Gourmet (İsviçre), Servair (Fransız), SATS (Singapur Changai Havalimanı merkezli), Flying Food 
Group (ABD ve Çin'de faaliyet göstermektedir.) ve Türkiye'de Turkish DO\&CO adiile faaliyet gösteren Avusturya merkezli DO\&CO olarak siralanabilmektedir (www.havayolu101.com).

Havayolları rekabet edebilmek için ikram hizmetlerinde farklı uygulamalarla daha çok tercih edilmeyi hedeflemektedir. Bu durumu bir örnekle Türk havayolu firmaları açısından değerlendirecek olursak Turkish DO\&CO'nun genel ikram hizmetlerinde dikkate aldığı bazı hususlar vardır. Uzun menzilli uçuşlarda business class yolcularına yemek hazırlama ve sunulması konusunda hizmet veren uçan aşçı uygulaması; yemeklerin servisi esnasında çeşitli uygulamalarla lüks bir restoran algısı oluşturmak, Türk yemek kültürünü tanıtabilmek ve aynı zamanda bütün yolcuların farklılıklarını göz önünde bulundurarak Türk ve dünya mutfaklarından menü örneklerinin kullanılması; uluslararası hijyen kurallarına uygun üretim yapılması; zamanın eğilimleri ve minimum lezzetler doğrultusunda daima geliştirilen yeni konseptler oluşturarak hizmetin sunulması; yolculara eşssiz deneyimler yaşatabilmek amaciyla butik üretim mantı̆̆ıyla çalışılması; uçuş esnasında ve loungelerde ikram servislerinin Türk misafirperverliğine uygun olarak yapılması; yolcuların memnuniyetini en üst seviyede tutabilmek amacıyla hizmet kalitesini sürekli ölçmek ve dolayısıyla kalite ve çözüm odaklı olunması; uçuş esnasında hizmet veren kabin görevlileri ve şeflere verilen eğitimin öneminin arttırılmasıbu hususlardan bazılarıdır (Yabacı, 2018).

Havayolu taşımacılığında servis edilen yemeklerin bir öğünde belirli kurallar dahilinde biraraya gelmesi ve bir sıra dahilinde servis edilmesi menü kavramının önemini ortaya koymaktadır. Menü, Latince'de "küçük-az" anlamına gelen "minutus" sözcügüunden türeyerek Fransızca'ya geçmiştir. Daha sonra yemek endüstrisinin de gelişmesiyle "bir öğün için, bir sıra dahilinde servisi yapılan, birbiriyle uyumlu yemekler grubu" tanımı olarak benimsenmiştir (Altınel, 2017). Menü aynı zamanda "işletmelerin müşterileriyle servis edilen yiyeceklerle ilgili olarak iletişime geçmesini sağlayan yazılı/resimli belge" anlamıla da kullanılmaktadır (Mooney, 1994).

Havayollarında menü planlama sürecini Jones (2004), Şekil 1'deki gibi açıklamaktadır.

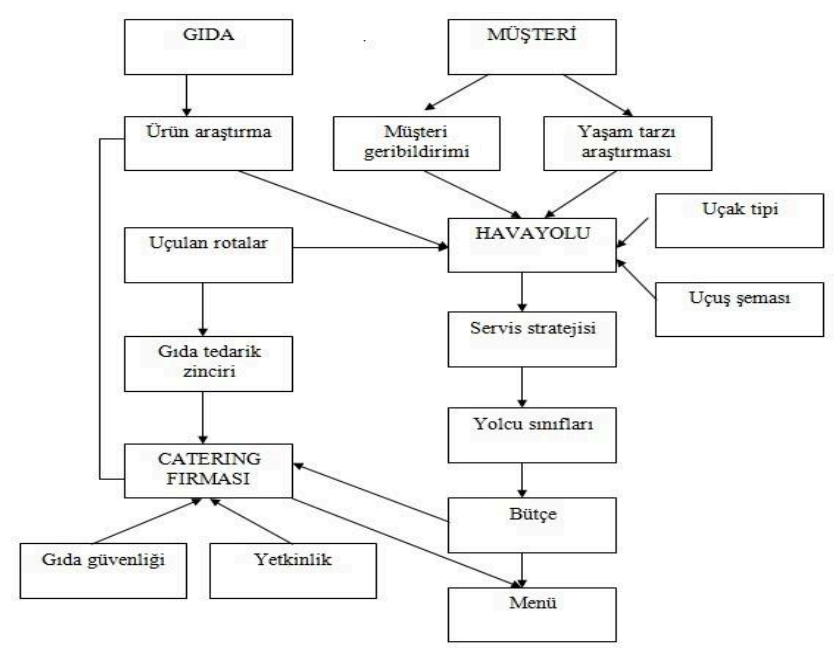

Şekil 1. Havayolu Ulaşımında Menü Planlama Süreci

Kaynak: Jones (2004: 78)

Şekil 1'den anlaşılacağı gibi havayolu taşımacılığında menü planlama süreci, içerisinde birçok faktörün olduğu oldukça zahmetli bir süreçtir. Uçaklarda servis edilecek yiyecek ve içeceklerin araştırılmasından tedarik edilmesine, yiyecek ve içeceklerin hazırlanmasından sorumlu catering 
firmalarının yetkinliği ve güvenlikle ilgili aldığı önlemlere, servisin yapılacağı uçak tipine, müşterilerin yaşam tarzlarından firmaların bütçelerine kadar tüm detayların profesyonelce yürütülerek menülerin planlanması gerekmektedir.

Havayolu taşımacılığında sadece Türkiye' de değil dünyada da bir değer haline gelen Türk Hava Yolları'nın menülerinden yola çıkarak menü planlamanın inceliklerini ve bazı standartları anlamamız mümkündür. Firma yurtiçi uçuşlar hariç herzaman tıbbi durumlar, beslenme alışkanlıkları ve dini inançlara göre misafirlerine "özel yemek" servisi yapmaktadır. Özel yemekler IATA (The International Air Transport Association) üyesi olan tüm havayolu kuruluşları için geçerlidir ve bazı kategorilere ayrılmaktadır. Bu kategorilerden hareketle firma tıbbi yemekler (kolay sindirilebilen, diyabetik, gluten içermeyen, düşük kalorili, meyve çeşitleri bulunan, az yağlı, az tuzlu, laktoz içermeyen), dini yemekler (Hindu yemekleri, Kosher yemekleri), vejetaryen yemekleri (Hint tipi, çiğ meyve-sebze yemekleri, vegan, Jain vejetaryen, Lacto-ovo vejetaryen, doğuya özgü vejetaryen), bebek yemeği, çocuk yemeği, kutlama pastası, deniz ürünleri yemeği, fındık-fıstık alerjisi olanlar için hazırlanan yemekler gibi seçeneklerle menülerini geniş tutmaktadır (www.turkishairlines.com.tr).

Türk havayolu firmalarının özellikle uzun menzilli uluslararası uçuşlarda dünya mutfaklarından seçeneklerin yanında Türk kültürüne ait yemekleri de menülerinde bulundurmaları ülke turizmine ve yemeklerin tanıtılmasına oldukça katkı sağlamaktadır. Başta Türk Hava Yolları olmak üzere diğer firmalar menülerinde yeralan Türk yemeklerini, oldukça usta bir şekilde yaparak yolculardan aldıkları beğeniler ve elde ettikleri başarılarbazı örneklerle karşımıza çıkmaktadır. ABD'nin ünlü ekonomi dergisi Forbes'ta, 2 Haziran 2019 tarihli “Five Things To Love About Turkish Airlines New Business Class Lounge" başlıklı haberde yazar Amber Gibson Türk Hava Yollarının üstün hizmet kalitesinin yanısıra Türk mutfak kültürüne ait menemen, ıspanaklı gözleme, mantı, ayran, simit, fava, Türk zeytinyağı, Trabzon tereyağı, yogurt, Türk peyniri gibi lezzetlerine hayranlığını ayrıntılı bir şekilde anlatmaktadır (www.forbes.com).

\section{Uçan Şefler}

Havayolu firmaları arasında her zaman bir rekabet olduğundan söz etmek mümkündür. Bu rekabet kimi zaman fiyat indirimi kimi zaman da hizmetlerde yenilik olarak kendini göstermektedir. İşte bu rekabetin en son örneklerinden biri de Business Class yolcularına sunulan yemeklerin hazırlanması için uzun uçuşlarda "Uçan Şef" bulundurulması uygulamasıdır. "Uçan Şef" yada "Flying Chef" olarak adlandırılan hizmet uzun mesafeli uçuşlarda kabin ekibinin bir parçası olarak mutfak eğitimi almış, deneyimli bir aşçının yolculara yemekleri özel bir şekilde sunması olarak tanımlanabilir. Burada amaçlanan sadece yolcuların doyurulmaları değil aynı zamanda havada geçirilen sürenin keyifli bir hale getirilmesidir. Bu işin öncüsü Türk Hava Yolları'nda çalışan uçan şeflerin hepsi zaten mutfak eğitimi almış kişilerdir. Bu nedenle eğitimlerinde daha çok uçaktaki uygulamalarla ilgili bilgiler verilmektedir. Turkish DO\&CO tesislerinde uçan aşçılara, şefleri tarafından uçakta yapılacak hizmetlerin detayları ve "galley" adı verilen uçaktaki mutfağın incelikleri hakkında bilgi verilmektedir. Eğitimde uçaktaki fırının ısısının nasıl olacağı, tabaklara yemeklerin nasıl yerleştirileceği ve uçaktaki sunumun incelikleri gibi pek çok konu üzerinde durulmaktadır (www.turkishairlines.com.tr).

Dünyada ve Türkiye'de gastronomi alanında çalışacak olan kişilerde yapılan işin çok hassas olması sebebiyle bazı kriterler aranmaktadır. Uçan şefler havacılık sektöründe giderek önemi artan kişilerdir ve bu nedenle sadece mutfak uygulamaları ve yemek pişirmede usta olmaları yetmemektedir. Bu açıdan bakıldığında uçan şeflerin farklı konularda donanımlı, bazı karakter 
özelliklerine ve fiziksel yeterliliklere sahip olması gerekmektedir. Bir örnekle bu konuya açıklık getirecek olursak Turkish DO\&CO 2018 yılında bir kariyer sitesi üzerinden "Uçan Şef" (Flying Chef-FC) ile "Uçan Servis Şefi" (Flying Service Chef-FSC) alımı için birtakım kriterler belirlemiştir. Bu kriterler şu şekildedir;

Tablo 1. Turkish DO\&CO'nun FC ve FSC Başvuruları İçin Belirlediği Kriterlerler

\begin{tabular}{|c|c|}
\hline FSC KRİTERLERİ & FC KRİTERLERİ \\
\hline $\begin{array}{l}\text {-En az } 2 \text { yıllık yüksekokul mezunu olmak } \\
\text { - Türkçe ve İngilizce'yi akıcı olarak } \\
\text { konuşmak } \\
\text { - Yüksek motivasyon ve hizmet tutkusu } \\
\text { - Takım çalışması, iletişim ve koordinasyon } \\
\text { becerilerine sahip olmak } \\
\text { - Tercihen mutfak veya misafirperverlikte } \\
\text { deneyimli olmak } \\
\text {-Seyahat kısıtlaması olmamak } \\
\text { - Düzgün vücut kitle indeksi ile } 160-180 \mathrm{~cm} \\
\text { arasinda olmak }\end{array}$ & $\begin{array}{l}\text { - } 5 \text { yıldızlı oteller, yolcu gemileri veya gurme } \\
\text { restoranlarında en az } 3 \text { yıllık mutfak } \\
\text { deneyimi } \\
\text { - Minimum lise, tercihen mutfak okulu } \\
\text { mezunu olmak } \\
\text { - Türkçe ve İngilizce'yi akıcı olarak } \\
\text { konuşmak } \\
\text { - Yüksek motivasyon ve hizmet tutkusu } \\
\text { - Takım çalışması, iletişim ve koordinasyon } \\
\text { becerilerine sahip olmak } \\
\text { - Güncel yemek bilgisine sahip ve restoran } \\
\text { trendleri konusunda bilgili olmak } \\
\text { - Erkek adaylar için askerlik yükümlülüğü } \\
\text { olmamak }\end{array}$ \\
\hline
\end{tabular}

Kaynak: www.kariyer.net

Tablo 1'den anlaşılacağı üzere havayollarında yiyecek içecek hazırlama ve servisi ile ilgili işe alınacak kişilerde birçok özellik aranmaktadır. FC başvurularında FSC adaylarından farklı olarak aşçılıkla iligili deneyimli olmaları, tercihen meslekleri ile ilgili okullardan mezun olmaları ve yeme-içme ile ilgili güncel konuları takip etme alışkanlıklarına sahip olmaları beklenmektedir. Bunun sebebi olarak da uçan şeflerin daha çok işin mutfağında yer almaları anlaşılmaktadır. Yine FC adaylarının erkek olmaları durumunda askerliklerini yapmış olmaları istenmektedir. FSC adaylarından ise daha çok işin servis kısmı ile ilgili olduğu için misafirperverlik konusunda deneyimli olmalarının yanı sira en az 2 yıllık üniversite mezunu olmaları, seyahat kısıtlamalarının bulunmaması ve bazı asgari fiziksel özelliklere sahip olmaları beklenmektedir. Her iki gruptaki şef adaylarından Türkçe ve İngilizce'yi akıcı bir şekilde konuşabilmelerinin istenmesi yolcu ile iletişim açısından çok önemli bir kriterdir. Yine aynı şekilde yüksek motivasyon, hizmet etme tutkusu, takım çalışmasına yatkınlık, iletişim becerileri gibi kişisel özellikler de şeflerde aranmaktadır. THY'nin uçan şef uygulamasının bir benzerini Saudia Arabian Airlines (SAUDIA) In-Flight Chef olarak uçaklarında yürütmektedir. SAUDIA, In-Flight Chef alımı için kariyer sitelerine verdiği ilanlarda şeflerde THY'nin şartlarına benzer şartlar aramaktadır. SAUDIA şeflerde ek olarak mutfağı temiz, hijyenik ve düzenli tutma; menü seçimlerinde yolculara güvenilir bilgiler verme; kişisel hijyen; baskı altında çalışabilme; görünür bir yerinde dövme olmaması ve çalışırken piercing takmama gibi kriterlere dikkat etmektedir (www.angel.co).

\section{YÖNTEM}

$\mathrm{Bu}$ araştırmada nitel araştırma yöntemlerinden görüşme tekniği kullanılmıştır. Görüşme, araştırma konusu ile ilgili uygun görülen kişiler ile soru-cevap şeklinde karşıllıklı konuşarak nitel veri toplama aracıdır. Görüşmeler esnasında yarı yapılandırılmış bir görüşme formu 
kullanılmıştır. Yarı yapılandırılmış görüşme yapılandırılmış görüşme türüne göre daha esnek olup, soruların sayısı ve sırası duruma göre değiştirilebilmektedir. Konunun gelişimine göre anlık olarak ek soruların da yöneltilmesi mümkündür. Bu aşamada araştırmacının konuya hakim olması gerekmektedir (Kozak, 2018: 81). Görüşmelerin derinlemesine yapılmasındaki amaç konunun bütün boyutlarını kapsayan, daha çok açık uçlu sorular sorarak detaylı cevaplar alınmasına imkan veren özelliğinin olmasıdır (Tekin, 2006: 101). Görüşme formunun hazırlanmasında araştırmacılardan uçan şef olarak çalışmakta olan Funda UĞRAÇ'ın konu ile ilgili bilgisi, diğer uçan şefler ile yapılan ön görüşmeler, havayolu firmalarının menü örnekleri ve konu ile ilgili literatür esas alınmış ardından sorular araştırmacılar tarafından hazırlanmıştır. Görüşme formunun son halini alması amacıyla kapsamlı bir literatür taraması yapılmış ve daha sonra hazırlanan sorular alanında uzman olan kişilere başvurarak forma eklenmiştir.

Araştırma kapsamında Türkiye'de faaliyet gösteren bir havayolu firmasının uzakdoğu uçuşlarında görevli ve 09-15 Aralık 2019 tarihlerindeki uçuşlarda görev alan 20 uçan şef ile görüşmeler yapılmıştır. Araştırmada uzakdoğu uçuşlarının seçilme nedeni, servis edilen menülerde bulunan Türk yemeklerinin diğer yemeklere oranla daha fazla yer almasıdır. Görüşmeler 10 dakika ile 35 dakika aralığında değişen sürelerde yapılmıştır. Görüşme formunda yeralan sorulara verilen cevapların daha iyi analiz edilebilmesi amacıyla uçan şeflerin de bilgisi dahilinde görüşmeler bir ses kaydedicisi ile kaydedilmiştir.

\section{BULGULAR}

Çalışmaya katılanların demografik özellikleri Tablo 2'de gösterilmiştir. Araştırma kapsamında uçan şef olarak çalışan 20 katılımcı ile görüşmeler yapılmıştır. Katılımcıların 8'i kadın, 12'si erkektir. Katılımcıların uçan şef olarak çalışma sürelerine bakıldığında çoğunluğunun (\%65) 5 yılınüzerinde mesleki deneyimlerinin olduğu görülmektedir. Uçan şef olarak 1 yılın altında iş tecrübesine sahip katılımcı sayısı ise 2 olarak tespit edilmiştir. Katılımcıların uçan şef olarak çalışmaya başlamadan önce tamamının aşçllı tecrübesinin olduğu ve önemli bir bölümünün (\%75) restoranlarda çalıştığı anlaşılmaktadır. Eğitim düzeyine bakıldığında 17 katılımcının lisans, 3 katılımcının yüksek lisans mezunu olduğu tespit edilmiştir. Yüksek lisans mezunu olankatılımcılardan bir kişinin ise doktora eğitimine devam ettiği tespit edilmiştir. Tablo 2'de en son mezun olunan eğitim düzeyi esas alındığı için bu durum tabloda ayrıca belirtilmemiştir.

Tablo 2. Katılımcların Demografik Özellikleri

\begin{tabular}{|c|c|c|c|c|c|c|c|c|}
\hline Cinsiyet & Say1 & $\%$ & $\begin{array}{l}\text { Uçan Şeflik } \\
\text { Tecrübesi }\end{array}$ & Sayı & $\%$ & $\begin{array}{c}\text { Daha } \\
\text { Önceki } \\
\text { Aşçılık } \\
\text { Tecrübesi }\end{array}$ & Say1 & $\%$ \\
\hline $\begin{array}{l}\text { Kadin } \\
\text { Erkek } \\
\text { Toplam }\end{array}$ & $\begin{array}{c}8 \\
12 \\
20 \\
\end{array}$ & $\begin{array}{r}40 \\
60 \\
100\end{array}$ & \multirow{3}{*}{$\begin{array}{l}1 \text { yıldan az } \\
1 \text {-5 yıl arasında } \\
5 \text { yıl üzeri }\end{array}$} & $\begin{array}{l}2 \\
5\end{array}$ & $\begin{array}{l}10 \\
25\end{array}$ & $\begin{array}{l}\text { Restoranda } \\
\text { Otelde }\end{array}$ & $\begin{array}{l}15 \\
3\end{array}$ & $\begin{array}{l}75 \\
15\end{array}$ \\
\hline Eğitim Durumu & Sayı & $\%$ & & \multirow[t]{2}{*}{13} & \multirow[t]{2}{*}{65} & \multirow[t]{2}{*}{$\begin{array}{l}\text { Cruise } \\
\text { Gemisinde }\end{array}$} & 2 & 10 \\
\hline $\begin{array}{l}\text { Yüksek Lisans } \\
\text { Lisans }\end{array}$ & $\begin{array}{c}3 \\
17\end{array}$ & $\begin{array}{l}15 \\
85\end{array}$ & & & & & & \\
\hline Toplam & 20 & 100 & Toplam & 20 & 100 & Toplam & 20 & 100 \\
\hline
\end{tabular}


Tablo 3. Menülerde Yer Alan Türk Mutfağına Ait Ürünler

\begin{tabular}{|l|l|}
\hline Başlangıçlar & $\begin{array}{l}\text { Humus, Tabule, Patlıcan Salatası, Kalem Böreği, Avcı Böreği, } \\
\text { Zeytinyağlı Tabağı, İmambayıldı, Ege Usulü Salata, Cacık, } \\
\text { Şakşuka, Muska Böreği, Beyaz Peynir. }\end{array}$ \\
\hline $\begin{array}{l}\text { Ana } \\
\text { Yemekler }\end{array}$ & $\begin{array}{l}\text { Kağıtta Levrek, Mantı, İslim Kebabı, Tirit Kebabı, Karnıarık, } \\
\text { Güveç Yemekleri, Kaygana, Menemen, Et Şiş, Tavuk Şiş, Kuzu Pirzola, } \\
\text { Etli Dolma, Dana Külbastı, Gözleme Çeşitleri }\end{array}$ \\
\hline Tatlılar & $\begin{array}{l}\text { İrmik Helvası, Baklava Çeşitleri, (Cevizli Baklava, Fıstıklı Sarma, Şöbiyet) } \\
\text { Balkabağı Tatlısı, Maraş Dondurması, Revani Ekmek Kadayıfı, Sütlaç. }\end{array}$ \\
\hline İçecekler & Salep, Türk Kahvesi, Demleme Çay, Ayran. \\
\hline
\end{tabular}

Araştırma kapsamında uçan şeflere görev yaptıkları uluslararası uçuşlardaki menülerde Türk mutfağına ait hangi ürünlerin yer aldığı sorulmuştur. Tablo $3^{\prime}$ te görüldügüü üzere alınan cevaplardan yola çıkılarak "Başlangıçlar","Ana Yemekler","Tatlılar","'İçecekler" şeklinde bir gruplandırma yoluna gidilmiştir. Menülerde başlangıç yemeklerinden; humus, tabule, patlıcan salatası, kalem böreği, avcı böreği, zeytinyağlı tabağı, imambayıldı, Ege usulü salata, cacık, şakşuka, muska böreği, beyaz peynir bulunmaktadır. Ana yemeklerden; kağıtta levrek, mantı, islim kebap, tirit kebap, karnıyarık, güveç yemekleri, kaygana, menemen, et şiş, tavuk şiş, kuzu pirzola, etli dolma, dana külbastı, gözleme çeşitleri, menülerde yer almaktadır. Menülerde tatlılardan ise; irmik helvası, cevizli baklava, fıstıklı sarma, şöbiyet, balkabağı tatlısı, Maraş dondurması, revani ekmek kadayıfı, sütlaç yer almaktadır. İçecek olarak ise menülerde; salep, Türk kahvesi, demleme çay, ayran bulunmaktadır.

Tablo 4. Menülerde Yer Alan Başlangıç, Ana Yemek, Tatlı ve İçeceklerinden En Çok Tercih Edilenler

\begin{tabular}{|l|c|c|l|c|c|}
\hline \multicolumn{1}{|c|}{ Başlangıçlar } & Sayı & \% & \multicolumn{1}{|c|}{ Ana Yemekler } & Sayı & \% \\
\hline Meze Tabağı & 10 & 50 & İslim Kebabı & 15 & 75 \\
Humus & 8 & 40 & Kağıtta Levrek & 7 & 35 \\
Tabule & 6 & 30 & Kuzu Pirzola & 6 & 30 \\
Kalem Böreği & 3 & 15 & Tirit Kebabı & 3 & 15 \\
Avcı Böreği & 2 & 10 & Karnıarık & 2 & 10 \\
Şakşuka & 2 & 10 & Dana Külbastı & 1 & 5 \\
Patlıcan Salatası & 1 & 5 & Mantı & 1 & 5 \\
Ege Usulü Salata & 1 & 5 & & & \\
\hline \multicolumn{1}{|c|}{ Tatlılar } & Sayı & \% & İçecekler & Sayı & \% \\
\hline Baklava Çeşitleri & 18 & 90 & Demleme Çay & 11 & 55 \\
Maraş Dondurması & 8 & 40 & Türk Kahvesi & 9 & 45 \\
Sütlaç & 1 & 5 & Ayran & 2 & 10 \\
İrmik Helvası & 1 & 5 & & & \\
\hline
\end{tabular}

Araştırma kapsamında uçan şeflere görev yaptıkları uçuşlardaki menülerde yer alan Türk yemek ve içeceklerinden diğerlerine göre daha fazla tüketilenler olup olmadığı sorulmuştur. Bu 
kapsamda uçan şeflere birden fazla ürün sayabilme yada hiçbir ürün söylememe serbestliği sağlanmıştır. Araştırmaya katılan tüm uçan şefler en az bir yemeğindiğerlerine oranla daha çok tercih edildiğini ifade etmiştir. Şeflerden sadece biri, herhangi bir içeceğin diğerlerine oranla daha çok tercih edilme durumunun olmadığı ifade etmiştir.

Tablo 4'e bakıldığında uçan şeflerin gözlemlerinden yola çıkılarak yolcuların çeşitli mezelerin bulunduğu meze tabağını diğer başlangıçlara göre daha çok tercih ettikleri anlaşılmaktadır. Yine bir meze çeşidi olan humusun yolcular tarafından meze tabağının ardından en çok tercih edilen başlangıç olduğu anlaşılmaktadır. Yolcuların yine daha çok tercih ettikleri başlangıçlar arasında börek çeşitleri, salata çeşitleri ve yine bir meze olan şakşukanın olduğu görülmektedir. Ana yemeklere bakıldığında ise genel olarak et yemeklerinin yolcular tarafından daha çok tercih edildiği anlaşılmaktadır. Özellikle kebap çeşitleri ana yemekler arasında en çok tercih edilenler olarak ifade edilmiştir. Uçan şefler bu durumu "Yolcular, içinde kebap kelimesi geçen tüm yemekleri denemek istiyor." şeklinde açıklamaktadır. Buradan hareketle kebap kelimesinin yabacılarda mutfak kültürümüzle ilgili oldukça olumlu bir imaj oluşturduğu anlaşılmaktadır. Albayrak (2013)'ın farklı milletlerden turistlerin Türk mutfağına ilişkin görüşlerinin saptanması üzerine yaptığı bir araştırmada turistlerin Türk mutfağından pide çeşitleri ve lahmacunla birlikte en çok kebap çeşitlerini tercih ettiği saptanmıştır. Yine yabancı turistlerin Türk mutfağ hakkındaki görüşlerinin incelendiği bir araştırmada katılımcıların büyük bir bölümünün Türkiye'de en çok kebap çeşitlerini (\%70.1) beğendikleri tespit edilmiştir (Sami, 2019). Şanlıer (2005)'in yabancı turistlerin Türk mutfağı hakkındaki görüşlerini inceledikleri başka bir araştırmada et yemeklerinden kebapların (\%57) en çok tercih edilen yemek olduğu belirlenmiştir. $\mathrm{Bu}$ araştırmaların bulguları çalışmamızla benzerlik göstermektedir. Araştırmamızda kebap çeşitlerini kağıtta levrek izlemiştir. Tatlılar arasında özellikle baklavanın yolcular tarafından en çok tercih edilen birinci tatlı olduğu anlaşılmaktadır. Baklavadan sonra sırasıyla Maraş dondurması, sütlaç ve irmik helvası yolcuların daha çok tercih ettikleri tatlılar arasında yer almaktadır. Uçan şeflerin ifadelerinden hareketle Maraş dondurmasının diğer dondurma çeşitlerinden daha yoğun ve elastiki bir yapısının olmasının yanı sıra farklı bir lezzetinin olması yolcuların ilgisini çekmektedir. Bu durumun dondurmayı tercih etme isteklerini arttırdığı söylenebilir. İçecek tercihlerine bakıldığında ise yolcuların en çok demleme çayı ve ardından Türk kahvesini tercih ettikleri ve ayranı bu iki içecek kadar olmasa da salepe göre daha çok tercih ettikleri anlaşılmaktadır. Uçan şefler özellikle demleme çayın kültürümüzde ince belli bardak olarak bilinen bardaklarda ve semaver ile servis edilmesinin yolcular tarafından çok otantik bulunduğunu ifade etmişlerdir. Uçan şefler servis edilen Türk yemekleriyle ilgili yolculardan sıklıkla olumlu dönütler aldıklarını ifade etmişlerdir. Uçan şeflerin bu durum ile ilgili ifadelerinden bazıları şöyledir:" Yolcular Türk mutfağını hem göze hem damağa hitap eden bir mutfak kültürü olarak görüyor."," Yolcular özellikle sunumlarımızı çok beğeniyor, tabaklar önlerine geldiğinde hayranca ve meraklı bakışlar hemen farkediliyor.","Yolcular ürünlerimizin kalitesini ve sunumlarımızı çok beğeniyor."

Tablo 5 'te uçan şeflerin gözünden menülerde yer alan yemek ve içeceklerden hangilerinin diğerlerine göre daha az tercih edildiğine yönelik bilgiler yer almaktadır. Başlangıç yemeklerinden yaprak sarmanın yolcular tarafından en az tercih edilen seçenek olduğu tespit edilmiştir. Yine bir uçan şefin ifadesinden yola çıkılarak Ege usulü salata da az tercih edilen başlangıçlardan biridir. Ana yemeklerden özellikle mantınındiğerlerine oranla daha az tercih edildiği uçan şefler tarafından ifade edilmiştir. Uçan şeflerden biri bu durumu mantının menü kartında "Turkish ravioli" olarak çevrilmesine fakat bu çevirinin mantı yemeğini tam olarak karşılayamamasına bağlamaktadır. Yine aynı şekilde, uçan şefler, avcı böreğinin "hunter's borek" olarak menü kartında yer almasının da yolcular tarafından yemeğin doğru algılanamamasına ve az tercih edilmesine sebep olduğunu ifade etmektedir. Uçan şeflerin önemli 
bir kısmı karnıyarık ve güveç gibi yemeklerin ilk seferinde yolcular tarafından karmaşık olarak algılandığını ifade etmişlerdir. Yolcuların bu yemeklere önyargılı yaklaştıklarını fakat şeflerin açıklamaları ile birlikte yapılan tadımlar sonucu beğeni düzeyinin arttı̆̆ını belirtmişlerdir. Tatlılara bakıldığında özellikle irmik helvasının yolcular tarafından daha az tercih edildiği ve sonra sırasıyla kabak tatlısı, sütlaç, revani ve ekmek kadayıfının da dahaz az tercih edilen menü seçenekleri olduğu anlaşılmaktadır. Bu durumla ilgili olarak uçan şefler "Yolcular irmik helvasını görünüşü sebebiyle pilava benzetiyor ve yemek istemiyor", "İrmik helvasının lezzeti yolcuların beklentilerini tam olarak karşılamıyor.", "İrmik helvası tuzlu bir yiyecek olarak algılanıyor", "Sütlaç yolcular tarafından görünüş olarak karışık bir tatlı olarak algılanıyor." şeklinde ifadelerde bulunmuşlardır. İçeceklerden ayran ve salebin çay ve Türk kahvesine oranla daha az tercih edildiği ifade edilmiştir. Bir uçan şef bu durumla ilgili olarak "Salebin yoğun kıvamlı görüntüsü yolcuların bu ürünü tercih etmemesine yönelik bir algı oluşturmaktadır." şeklinde ifadede bulunmuştur.

Tablo 5. Menülerde Yer Alan Başlangıç, Ana Yemek, Tatlı ve Içeceklerinden En Az Tercih Edilenler

\begin{tabular}{|l|c|c|l|c|c|}
\hline \multicolumn{1}{|c|}{ Başlangıçlar } & Sayı & $\mathbf{9}$ & \multicolumn{1}{|c|}{ Ana Yemekler } & Say1 & \% \\
\hline Yaprak Sarma & 8 & 40 & Mantı & 8 & 40 \\
Ege Usulü Salata & 1 & 5 & Avcı Böreği & 1 & 5 \\
& & & $\begin{array}{l}\text { Etli Dolma } \\
\text { Tavuk Şiş }\end{array}$ & 1 & 5 \\
& & & Güveç Yemekleri & 1 & 5 \\
\hline \multicolumn{1}{|c|}{ Tatlılar } & Sayı & $\mathbf{\%}$ & \multicolumn{1}{|c|}{ İçecekler } & Say1 & \% \\
\hline İrmik Helvası & 7 & 35 & Ayran & 8 & 40 \\
Kabak Tatlısı & 5 & 25 & Salep & 6 & 30 \\
Sütlaç & 1 & 5 & & & \\
Revani & 3 & 15 & & & \\
Ekmek Kadayıfı & 1 & 5 & & & \\
\hline
\end{tabular}

Tablo 6. Yolcuların Türk Mutfağını Tercih Etmeme Nedenlerine Ait Uçan Şeflerin Görüşleri

\begin{tabular}{|l|c|c|}
\hline \multicolumn{1}{|c|}{ Uçan Şeflerin Görüssleri } & n & \% \\
\hline Yemek ve içeceklerimizi bilmedikleri için risk almak istemiyorlar & 10 & 50 \\
\hline Yemeklerimizi baharatlı buluyorlar & 7 & 35 \\
\hline Yemeklerimizi yağlı buluyorlar & 7 & 35 \\
\hline Kültürlerine uymadığı için yemek ve içeceklerimizi tercih etmiyorlar & 6 & 30 \\
\hline
\end{tabular}

Tablo 6'ya bakıldığında uçan şefler menülerde yer alan Türk yemekleri ve içeceklerini tercih etmeyen yolcuların tercih etmeme nedenlerine ait gözlemlerini dört madde altında ifade etmişlerdir. Özellikle yolcuların Türk mutfak kültürüne ait menülerde yer alan yemeklerden ve içeceklerden daha önce hiç tatmadıklarına karşı önyargılı davranması göze çarpmaktadır. Üzülmez (2018) tarafından yapılan yabancı turistlerin Türk mutfağı seçim motivasyonlarının incelendiği bir araştırmada, turistlerin yeni yiyecekleri deneme korkusuna yönelik veriler toplanmıştır. Katılımcıların \%52.9'u Türk mutfağı ile ilgili neofobik eğilimli, yani yeni yemekleri deneme korkusuna sahip oldukları tespit edilmiştir. Araştırmadaki "Bir yemeğin içeriğinin ne olduğunu bilmiyorsam o yemeği denemem.", "Etnik yiyeceklerin görüntüsü oldukça tuhaftır.", "Daha önce hiç denemediğim yiyecekleri denemekten korkarım.", "Yeni yiyeceklere güvenmem." gibi neofobik eğilime yönelik ifadeler uçan şeflerin ifadeleriyle benzerlik göstermektedir.Araştırmamızda yolcuların Türk yemeklerini baharatlı ve yağlı bulmaları 
sebebiyle tercih etmeme durumu Albayrak (2013)'ın yaptığı araştırma ile benzerlik göstermektedir. Söz konusu araştırmadaki verilere göre yabancı turistler Türk yemeklerini fazla baharatlı (\%55.5) ve fazla yağlı (\%54.6) bulmaktadır.

Tablo 7. Türk Mutfağını Tercih Etmeyen Yolcuların Tercih Ettiği Mutfaklarla İlgili Uçan Şeflerin Görüşleri

\begin{tabular}{|l|c|c|}
\hline \multicolumn{1}{|c|}{ Uçan Şeflerin Görüşleri } & n & \% \\
\hline Dünya mutfaklarını tercih ediyorlar & 8 & 40 \\
\hline Kendi ulusunun mutfağını tercih ediyorlar & 6 & 30 \\
\hline Akdeniz mutfağını tercih ediyorlar & 5 & 25 \\
\hline
\end{tabular}

Tablo 7 'de Türk mutfağına ait yemek ve içeceklerini tercih etmeyen yolcuların hangi mutfak kültürüne ait ürünleri tercih ettiklerine yönelik uçan şeflerin gözlemleri bulunmaktadır. Tablodan anlaşılacağı üzere yolcular öncelikle dünya mutfaklarına yönelmektedir. Yine yolcuların ikinci sırada kendi uluslarına ait ürünleri tercih ettikleri anlaşılmaktadır. Bu durumu Üzülmez (2018)'in neofobik eğilimlerle ilgili yaptığı araştırmadaki ifadelerle ilişkilendirebiliriz. Daha önce de belirttiğimiz gibi insanlar zaman zaman yeni deneyimler yaşamaktan korkmakta ve alışkın olduğu tarzda devam etme eğiliminde olmaktadır. Yine yolcularla ilgili gözlemlerden yola çıarak Türk mutfağı yerine aslında ortak noktalarımız bulunan Akdeniz mutfağının tercih edildiği anlaşılmaktadır.

Araştırma kapsamında görüşme yapılan 20 uçan şeften 12'si (\%60) yolcuların Türk yemekleri ve içeceklerine aşina olduklarını ifade etmişlerdir. Fakat daha önceki verilerden anlaşılacağı üzere bazı ürünlerin yolcular tarafından hiç bilinmediğini ve yanlış algılandığını da eklemişlerdir. Uçan şeflerin tümü Türk yemek ve içecekleri hakkında bilgi sahibi olmayan yolculara yemek ve içecekleri, hazırlanışından sunumuna kadar detaylı olarak açıklayarak yardımcı olmaya çalıştıklarını ifade etmişlerdir. Bir katılımcı "Yaprak sarma hakkında pek çok yolcunun hiçbir fikri olmuyor. Yemeğin isminden de bir çıkarımda bulunamıyor. Fakat biz anlattıktan sonra ve tattıktan sonra beğeniyorlar." şeklinde bir ifadede bulunmuştur. Karaosmanoğlu (2017)'nun uçuş-içi yiyecek içecek hizmetinin müşteri memnuniyetine etkisini incelediği bir araştırmada, uçuş-içi yiyecek içecek hizmetinden doğan memnuniyet ile genel uçuş deneyimi arasında ve yolcuların gelecekteki havayolu firması tercihlerine etkisi arasında anlamlı bir ilişkinin olduğu tespit edilmiştir. Yine aynı araştırmada kabin ekibinin ilgisi uçuş deneyimi açısından büyük oranda (\%81.3) önemli bulunmuştur.

Görüşme yapılan uçan şeflere, uçuşlarda kullanılan menülerde monotonluk yaşanıp yaşanmadığı sorulduğunda ise tamamı mevcut menülerin ayda dört kez dönüşümlü olarak servis edilmesi sebebiyle yolculardan bu konuyla ilgili olumsuz görüşler almadıklarını ifade etmiştir. Hatta katılımcılar kendilerinin bile çoğu kez aynı menüyle karşılaşmadıklarını söylemişlerdir. Katılımcılardan biri "Yalnızca haftada iki kez aynı yere seyahat eden yolcu belki aynı menü ile karşılaşabilir fakat bu noktada da yemeklerin sayısının fazlalığı bu sorunu ortadan kaldırabilir." şeklinde bir ifade kullanmıştır.

Uçan şeflere yürütülen bu çalışmayla ilgili fikirleri sorulduğunda tümü araştırmayı değerli bulduklarını ifade etmişlerdir. Uçan şefler yolcuların yiyecek ve içeceklerle ilgili tutumlarını doğrudan gözlemleyebildiklerini ve bunun da bu çalışmada sorulan sorulara en iyi şekilde cevap verebilmelerine olanak sağladığını ifade etmişlerdir. Bir katılımcı yabancı yolcuların Türk mutfağına ait düşüncelerinin öğrenilmesi adına yapılan bu çalışmada kendi görüşlerinin önemli bir referans olabileceğini belirtmiştir. Ayrıca uçan şefler kendileriyle daha önceden röportaj 
yapılmasına rağmen böyle bir bilimsel çalışmanın ilk defa yapıldığını ve uçan şeflik kavramının bir meslek dalı olarak dikkate alınmasından dolayı memnuniyetlerini belirtmişlerdir.

\section{TARTIŞMA, SONUÇ VE ÖNERILER}

Çalışmanın, uçan şeflerin demografik verileriyle ilgili kısmı incelendiğinde, katılımcılar arasında yüksek lisans mezunlarının da uçan şef olarak çalışıyor olması sektördeki hizmet kalitesinin arttığı ile ilişkilendirilebilir. Buradan hareketle uçan şef olmayı hedefleyenlerin eğitimlerinde lisans düzeyiyle yetinmemeleri önerilmektedir. Ayrıca uçan şeflerin kendilerini akademik olarak geliştirmesi, yolcularla olan iletişimlerini olumlu yönde etkileyerek, yolcu sadakatini arttıracak ve ülke turizmine katkı sağlayacaktır. Uçan şeflerin, daha önce belirtildiği gibi iletişim becerileri ve samimiyetlerinin yüksek olması ile yemeklerin yolcular tarafından anlaşılması arasında doğrudan bir ilişki olabileceği düşünülmektedir. Akgöl ve Birdir (2015)'in yabancı turistlerin gastronomi deneyimlerinin değerlendirilmesine yönelik yaptığı bir araştırmada, turistlerin tatmin düzeyine etki eden unsurlardan "personelin misafiri karşılaması ve uğurlaması" ile "personelin samimiliği ve içtenliği" unsurlarının diğer unsurlar arasında yüksek ortalamalara sahip olması, uçan şeflerde istenen özelliklerin ne kadar doğru olduğunu göstermektedir.

Yapılan araştırmanın sonucunda uluslararası uçuşlardaki Türk mutfağına ait yemeklerle ilgili yabancı yolcuların çoğunlukla olumlu görüşe sahip oldukları görülmektedir. Araştırmada elde edilen bulgular doğrultusunda yolcuların, Türk yemeklerini özgün, lezzetli ve doyurucu bulduklarını söylemek mümkündür. Uluslararası platformlarda, kebap örneğinde olduğu gibi, Türk mutfağıyla özdeşleşmiş ürünlerin mevcut menülerde oldukça fazla ilgi gördüğü sonucuna da ulaşılmıştır. Bununla beraber meze çeşitleri, baklava çeşitleri, Maraş dondurması, Türk kahvesi ve demleme çayda görüldüğü üzere, yolcuların Türk mutfağına ait bazı ürünleri denemeye açık oldukları anlaşılmaktadır. Bunun sebebi olarak da bu öğelerin Türk mutfak kültürünü yansıtan ve ülke tanıtımı faaliyetlerinde sıkça kullanılan ürünler olması gösterilebilir. Nitekim Altaş (2017)'ın ülke tanıtım çalışmaları kapsamında kullanılan afişler üzerine yaptığı bir araştırmasında, Türk kahvesi, çay ve baklavanın sıkça kullanılan görsel öğeler olduğunu ifade etmesi de bu görüşü desteklemektir. Bununla birlikte uluslararası bilinirliği olmayan, Türk mutfağına ait ürünlerin debu menülere eklenmesi durumunda bu yemeklerin yabancı yolcular arasında beğenilebileceği düşünülmektedir. Aynı şekilde bilinirliği fazla olan ürünler üzerinde yapılacak farklılaştırma çalışmaları sayesinde ürün çeşitlendirilmesi yapılabilir.

Ayrıca araştırmada yaprak sarma, mantı, irmik helvası ve salep gibi bazı ürünlerin yolcular tarafından daha az tercih edildiği ya da beğenilmediği tespit edilmiştir. Bu durumun farklı sebepleri olabileceği gibi, çalışmada edinilen bilgilere göre Türk mutfak kültüründeki yemek pişirme yöntemlerinin de bunda etkisi olabilir. Türk mutfak kültüründe ürünlerin eklenerek pişirilmesi, hem içerik hem de görünüş olarak yolcular tarafından karışık bulunmalarının ve mesafeli durmalarının nedeni olabilir. Bunun engellenebilmesi için de bu tarz yemeklerin hazırlanmasında ve sunulmasında kullanılan yöntemlerin farklılaştırılması önerilebilir. Yolcuların bazı ürünleri daha az tercih etmelerinde neofobik (yeni şeyleri deneme korkusu) eğilimlerin de etkili olabileceği düşünülmektedir. Bu noktada uçan şeflerin devreye girerek yolculara bu yemeklerle ilgili daha ayrıntılı bilgiler vermesi ve kaygılarını gidermesi uygun olacaktır.

Araştırmada elde edilen bulgulara göre yolcuların Türk yemeklerini fazla yağlı ve baharatlı buldukları görülmektedir. Buradan hareketle, yemeklerin yağ ve baharat oranlarının yolcuların beğenileri doğrultusunda değiştirilmesi önerilebilir. Türk mutfağına ait ürünleri yağlı ve 
baharatlı bulmalarından dolayı diğer dünya mutfaklarına yönelen yolcuların bu eğilimleri alınan bu tedbirle değiştirilebilir.

Ayrıca menü kartında yer alan bazı ürünlerin isimlerinin yabancı dile çevirilerinin o ürünleri temsil etmede yetersiz kalması, bu ürünlerin daha az tercih edilmelerinin sebeplerinden biri olabilir. Bu nedenle mantı-Turkish ravioli örneğinde olduğu gibi, bazı belirgin ürünlerin isimlerinin yabancı dile çevrilmesi yerine orijinal hallerinin korunması önerilmektedir. Ayrıca menu kartlarına bu tarz ürünlerin yanına içeriğiyle ile açıklayıcı metin eklenmesi önerilebilir.

Araştırma kapsamında uçan şeflerden alınan bilgiler ışığında, uluslararası uçuşlarda seyahat eden yabancı yolcuların önemli bir kısmı Türkiye'deki havaalanlarından çıkmadan transit yolculuk yapmaktadır. Bu yolcuların bir kısmının Türkiye'yi daha once hiç ziyaret etmediği düşünüldügünde, havalimanlarında ve uçuşlarda servis edilen menülerde yer alan Türk mutfak ürünlerinin önemi ortaya çıkmaktadır. Buna ek olarak uçan şeflerin yolcularla olan iletişimi de yolcuların gastronomi turizmi açısından olumlu fikre sahip olmalarına sebep olacaktır.

$\mathrm{Bu}$ çalışmada uçan şefler aracılı̆̆ıyla yolcuların yemek ve içecek tercihleri belirlenmeye çalışılmıştır. Gelecek çalışmalarda yolcuların bizzat kendileriyle yapılacak araştırmaların sonuçlarının bu araştırmanın sonuçlarıyla karşılaştırılabileceği ve Türk mutfağına yönelik algının farklı bakış açılarıyla değerlendirilebileceği düşünülmektedir.

\section{KAYNAKLAR}

Ahipaşaoğlu, H. S. ve Arıkan, İ. (2003). Seyahat İşletmeleri Yönetimi ve Ulaştırma Sistemleri, Ankara: Detay Yayıncilık.

Airnewstimes.com (2019) http://www.airnewstimes.com/iste-thy-nin-ucan-sefleri-7161-haberi.html [Erişim Tarihi: 22.11.2019].

Albayrak, A. (2013). Farklı Milletlerden Turistlerin Türk Mutfağına İlişkin Görüşlerinin Saptanması Üzerine Bir Araştırma, Journal of Yasar University, 30(8): 5049-5063.

Altaş, A. (2017). Ülke Tanıtım Çalışmaları Kapsamında Kullanılan Gastronomik Ögeler: “Home of Turkey" Kampanyası Afişleri Üzerine Bir Araştırma, Journal of Tourism and Gastronomy Studies, 5(2): 81-102

Altınel, H. (2017). Gastronomik ve Beslenme Ilkelerinden Hareketle Menü Planlama ve Yönetimi. (3. Basım), Detay Yayıncilık. Ankara.

Angel.co (2019) https://angel.co/company/saudi-arabian-airlines-3/jobs/460358-in-flight-chef [Erişim Tarihi: 24.11.2019].

Bakırcı, M. (2012). Ulaşım Coğrafyası Açısından Türkiye'de Havayolu Ulaşımının Tarihsel Gelişimi ve Mevcut Yapısı, Marmara Coğrafya Dergisi, 1(25): 340 - 377.

Birdir, K. ve Akgöl, Y. (2015). Gastronomi Turizmi ve Türkiye'yi Ziyaret Eden Yabancı Turistlerin Gastronomi Deneyimlerinin Değerlendirilmesi, İşletme ve İktisat Çalışmaları Dergisi, 3(2): 57-68.

Chuang, R. Y. (1971). The International Air Transport Association: A Case Study of A QuasiGovernmental Organization, A.W. Sijthoff İnternational Publishing Company, s.16

Dana, L. P. (1999). Korean Airlines, British Food Journal, 101(5): 113-116. 
Forbes.com (2019) https://www.forbes.com/sites/ambergibson/2019/06/02/five-things-to-love-aboutturkish-airlines-new-business-class-lounge/\#6d855c89231b [Erişim Tarihi: 22.11.2019].

Gataairlines.com (2019) https://gatairlines.com/dunya-havacilik-tarihi-ve-bizim-hikayemiz/ [Erişim Tarihi: 20.11.2019].

Havayolu101.com (2019) https://www.havayolu101.com/2013/04/01/havayolu-catering-ikramsirketleri/ [Erişim Tarihi: 25.11.2019].

Jones, P. (2004). Flight Catering, Butterworth Heinemann: Oxford.

Kane, R. M. (1990). Air Transportation, Kendall/Hunt Publishing Company ,10 st Edition içinde (ss. 1-3)

Karaosmanoğlu, K. (2017). Uçuş-içi Yiyecek İ̧̧ecek Hizmetinin Müşteri Memnuniyetine Etkisi, Yüksek Lisans Tezi, Adnan Menderes Üniversitesi, Aydın.

Kariyer.net (2019) https://wwww.kariyer.net/firma-profil/turkish-do-co-12972-42079 [Erişim Tarihi: 15.11.2019].

Kozak, M. (2018). Bilimsel Araştırma: Tasarım, Yazım ve Yayım Teknikleri. (3. Basım), Ankara: Detay Yayıncilık. s. 81-84

Mooney, S. (1994). Planning and Designing the Menu, (Editörler) Jones, P. and Merricks, P. The Management of Foodservice Operations: An integrated and innovative approach to catering management, içinde Cassell: London, 45-58.

Pilling, M. (2001). Food for Thought. Airline Business, Jan. 48-50.

Sami, F. (2019). Yabancı Turistlerin Türk Mutfă̆ı Hakkındaki Görüşlerinin Gastronomi Turizmi Çerçevesinde Incelenmesi: Atatürk Havalimanı Bölgesi Otelleri Üzerine Bir Araştırma, Yüksek Lisans Tezi, Okan Üniversitesi, İstanbul.

Superadrianme.com (2019) https://www.superadrianme.com/travel/airline/inflight-flying-chefs/ [Erişim Tarihi: 25.11.2019].

Şanlıer, N. (2005). Yerli ve Yabancı Turistlerin Türk Mutfağı Hakkındaki Görüşleri, Gazi Üniversitesi Ĕ̆itim Fakültesi Dergisi, 25(1): 213-227.

Tekin, H. H. (2006). Nitel Araştırma Yönteminin Bir Veri Toplama Tekniği Olarak Derinlemesine Görüşme, Sosyoloji Dergisi, 3(13): 101-116.

TUBITAK, (2003). Vizyon 2023 Ulaştırma ve Turizm ön Paneli Ön Raporu. s.12 https://www.tubitak.gov.tr/tubitak_content_files/vizyon2023/ut/utp_son_surum.pdf. [Erişim Tarihi: 22.11.2019].

Turkisairlines.com (2019). https://www.turkishairlines.com/tr-us/ucak-bileti/ucus-deneyimi/ucak-iciikram/ [Erişim Tarihi: 20.11.2019].

Üzülmez, M. (2018). Yabancı Turistlerin Türk Mutfağı seçim Motivasyonlarının Neofobi ve Neofili Düzeylerine Göre İncelenmesi: İstanbul'da Bir Araştırma, Doktora Tezi, Mersin Üniversitesi, Mersin.

Yabacı, F. (2018). Havayolu Ulaştırma İşletmelerinin Tercih Edilmesinde Yiyecek İçecek Hizmet Kalitesinin Rolüne İlişkin Bir Araştırma (THY Örneği), Yüksek Lisans Tezi, Balıkesir Üniversitesi, Balıkesir. 